\title{
Anaerobic Digestion of Cotton Yarn Wastes for Biogas Production: Feasibility of Using Sawdust to Control Digester Temperature at Room Temperature
}

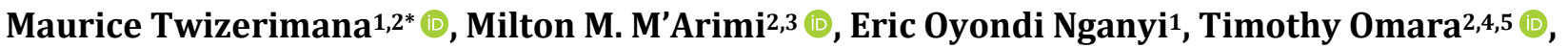 \\ Elly Olomo ${ }^{2,6} \mathbb{B}^{\text {, Nyirenda Austin Kawelamzenje }}{ }^{7}$
}

\begin{abstract}
${ }^{1}$ Department of Manufacturing, Industrial and Textile Engineering, School of Engineering, Moi University, Eldoret, Kenya
${ }^{2}$ Africa Center of Excellence II in Phytochemicals, Textiles and Renewable Energy (ACE II PTRE), Moi University, Eldoret, Kenya ${ }^{3}$ Department of Chemical and Process Engineering, School of Engineering, Moi University, Eldoret, Kenya

${ }^{4}$ Department of Chemistry and Biochemistry, School of Sciences and Aerospace Studies, Moi University, Eldoret, Kenya

${ }^{5}$ Department of Quality Control and Quality Assurance, AgroWays Uganda Limited, Kyabazinga Way, Jinja, Uganda

${ }^{6}$ Department of Mechanical, Production and Energy Engineering, School of Engineering, Moi University, Eldoret, Kenya

${ }^{7}$ Malawi University of Science and Technology, Thyolo, Malawi

Email: *twizerimanamaurice@gmail.com
\end{abstract}

How to cite this paper: Twizerimana, M., M’Arimi, M.M., Nganyi, E.O., Omara, T., Olomo, E. and Kawelamzenje, N.A. (2021) Anaerobic Digestion of Cotton Yarn Wastes for Biogas Production: Feasibility of Using Sawdust to Control Digester Temperature at Room Temperature. Open Access Library Journal, 8: e7654.

https://doi.org/10.4236/oalib.1107654

Received: June 16, 2021

Accepted: July 24, 2021

Published: July 27, 2021

Copyright (c) 2021 by author(s) and Open Access Library Inc.

This work is licensed under the Creative Commons Attribution International License (CC BY 4.0).

http://creativecommons.org/licenses/by/4.0/

\section{(c) (i) Open Access}

\begin{abstract}
Environmental and energy conservation pressure have led into intensive search for green sources of energy. One of the options being explored is generation of biogas from cellulosic (biodegradable) wastes. However, maintaining temperature for optimum biogas production is often an existential challenge. The materials/equipment used to control temperature is expensive as most of them require electricity. In this study, we investigated the feasibility of using a locally available material (sawdust) in anaerobic digestion (AD) of cotton yarn wastes (CYW) for biogas production. Two-liter digesters were set at room temperature, in a water bath and in sawdust using CYW as the substrate and cow dung as the inoculum. Biogas yields were recorded using water displacement method for 30 days and the effect of temperature was examined in each case. Results of the study indicated that the digester whose temperature was controlled using sawdust showed consistency in biogas production. Digester in the water bath showed the highest biogas yield compared to the digester controlled using sawdust and the one at room temperature with biogas yields of $2481.23 \pm 5.50 \mathrm{~mL}$ per $\mathrm{g}$-VS, $1856.51 \pm 6.98 \mathrm{~mL}$ per $\mathrm{g}$-VS and $1084.29 \pm 5.71$ $\mathrm{mL}$ per $\mathrm{g}$-VS, respectively. Similarly, the digester operated at control temperature using water bath had higher methane content $62.35 \%$ followed by digester in sawdust and then uncontrolled one with $52.45 \%$ and $45.28 \%$ respec-
\end{abstract}


tively. The results of our study indicate that sawdust has the potential of regulating temperature in the range that allowed $\mathrm{AD}$ of $\mathrm{CYW}$ for biogas production. Therefore, CYW and sawdust which are readily available materials can be harnessed for biogas production at room temperature.

\section{Subject Areas}

Renewable

\section{Keywords}

Cotton Yarn Waste, Sawdust, Control Digester Temperature, Optimum Biogas Production, Anaerobic Digestion

\section{Introduction}

There has been an increasing need to meet the United Nations energy and climate targets indicated in the 17 aspirational Sustainable Development Goals. These have primarily focused on using green energy sources to reduce the impacts of decadal climate change. Wind and solar energy are the most well-established renewable sources of energy, particularly in European countries [1]. Another potential renewable energy source that has gained global attention is biogas because of its potential to solve waste disposable problems, facilitate carbon sequestration and act as a buffer to erratic electricity supply [1] [2].

Biogas is produced by microbial degradation of carbonaceous compounds in anaerobic conditions (anaerobic digestion, AD) [3]. This process occurs in four distinct phases (namely: hydrolysis, acidogenesis, acetogenesis and methanogenesis) in the presence of a consortium of synergistic anaerobic microbes [4]. Hydrolytic bacteria first break down complex organic polymers like carbohydrates and proteins into simple soluble monomers. Acidogenic bacteria then consume the products of hydrolysis, converting them into simple volatile fatty acids and simple alcohols [5]. Further fermentation of the organic acids and carbon dioxide $\left(\mathrm{CO}_{2}\right)$ occur via acetogenesis, forming acetic acid, hydrogen and carbon dioxide which are the direct substrates for methane $\left(\mathrm{CH}_{4}\right)$ production [6]. Methanogenic bacteria generate $\mathrm{CH}_{4}$ mostly from acetic acid and the remainder from hydrogen and $\mathrm{CO}_{2}$ [7] [8]. After digestion, organic material is stabilized and gaseous byproducts (primarily $\mathrm{CH}_{4}$ and $\mathrm{CO}_{2}$ ) are released [8] [9]. Normally, $\mathrm{AD}$ operates in the mesophilic $\left(25^{\circ} \mathrm{C}\right.$ to $\left.40^{\circ} \mathrm{C}\right)$ or thermophilic $\left(40^{\circ} \mathrm{C}\right.$ to $\left.60^{\circ} \mathrm{C}\right)$ temperature ranges where most of the methanogens are active [9] [10]. However, methanogenesis can also occur at low temperatures $\left(>20^{\circ} \mathrm{C}\right)$, a process termed psychrophilic digestion. Thus, methanogens are classified as psychrophilic, mesophilic or thermophilic, contingent on the foregoing working temperature range [11]. AD at psychrophilic temperature has not been as extensively explored as either mesophilic or thermophilic AD [6].

Anaerobic digestion in biogas production depends on the substrate used, sol- 
ids loading, operating temperature and the hydraulic retention time [9]. Therefore, by controlling $\mathrm{AD}$ of cotton yarn wastes (CYW), methane emission from disposed CYW could be reduced. Anaerobic digestion of CYW for biogas production has been barely investigated. Isci and Demirer [12] studying anaerobic treatability and methane generation potential of various cotton wastes in batch reactors reported that the wastes were potential substrates for biogas production. An analogous conclusion was drawn by Rasel et al. [13] after investigating the potential of cotton (spinning, knitting and cutting) wastes in biogas production. Only one study in our laboratory [14] reported exclusively on biogas production from CYW but examined the feasibility of its co-digestion with human urine. It was found that the presence of human urine in AD of CYW enhanced biogas production by more than $35.6 \%$, demonstrating that human urine could be an effective waste for co-digestion of solid wastes such as CYW [14].

Normally, fresh cow manure containing mesophilic microbes is used as a cheap and readily available inoculum (source of methanogens) [14] [15] [16]. Addition of manure to anaerobic digesters simultaneously supplies microbes and organic material, allowing conversion of organic matter to biogas. However, the metabolism of mesophilic bacteria slows or shuts down at $20^{\circ} \mathrm{C}-25^{\circ} \mathrm{C}$ [17]. This requires that digesters should be stored indoors, incubated in a water bath, heated or completely retired in the cold season. The materials/equipment used to control temperature are expensive as most of them require electricity. If solutions to this temperature limitation were achieved, biogas technology could be proved as an excellent alternative energy source for communities, especially those which face particularly high costs of fuel and have paid high rate capita for energy consumption due to cold climates [18]. Interestingly, psychrophilic methanogens have been shown to produce biogas during winters [17]. However, temperature control is usually an existential struggle in biogas production as fluctuations in temperature can cause digester failure [19]. Vu et al. [20] reported that insulating the surface and digging the digester deeper into the soil could contribute to a higher digester temperature during cold conditions. Christy et al. [21] maintained that heat losses in $\mathrm{AD}$ biogas production can be avoided by insulating the digester cover. In this context, Park et al. [22] reported that mud temperature increased with increase in the internal depth of the digester during thermophilic acid fermentation of kitchen wastes. Temperature of air entering a biogas digester during cold conditions may be affected by different factors, but it is mainly affected by the air temperature and the degree of heat exchange between the digester and the digester and air among others [20] [23] [24]. To find out a simple way of maintaining temperature during cold conditions, it is important to understand the factors influencing the digester temperature [25]. As an extension of our study [14], the objective of the current study was to improve the efficiency of a biogas digester operating at cold temperatures by using a locally available material (sawdust). Specifically, the effect of sawdust in controlling temperature in the digester, and the consequent effect on biogas production using CYW 
as the substrate were investigated.

\section{Material and Methods}

\subsection{Substrate and Inoculum Collection, Preparation and Characterization}

The CYW used as the substrate in this study were collected from at Rivatex Eastern Africa Limited, Eldoret, Kenya while the inoculum (cow dung) was obtained from Moi University main campus farm. CYW were cut into small pieces using a pair of scissors (to facilitate biodegradation) and kept in the laboratory for a week (Figure 1). Its temperature was monitored daily using a handheld thermometer.

About $10 \%$ of the total volume working reactor was used as inoculum [14] [15]. The inoculum was kept refrigerated at $4^{\circ} \mathrm{C}$ for two days before use to minimize degradation and preserve integrity of microorganisms in it. It was used without subjection to any further treatments.

The CYW was characterized for its initial total solids (TS), volatile solids (VS), moisture content $(\mathrm{MC}), \mathrm{pH}$, carbon to nitrogen $(\mathrm{C} / \mathrm{N})$ ratio and ash content. The TS, VS and MC were characterized following the standard methods for Examination of Water and Wastewater [26]. The VS, TS and MC (calculated on a wet basis) were computed using Equations (1), (2) and (3) [27].

$$
\begin{aligned}
& \mathrm{TS}=\frac{\left(W_{3}-W_{1}\right)}{\left(W_{2}-W_{1}\right)} \times 100 \\
& \mathrm{VS}=\frac{\left(W_{3}-W_{4}\right)}{\left(W_{3}-W_{1}\right)} \times 100 \\
& \mathrm{MC}=\frac{\left(W_{2}-W_{3}\right)}{W_{2}} \times 100
\end{aligned}
$$

From which $W_{1}=$ Weight of crucible, $W_{2}=$ weight of wet material and crucible, $W_{3}=$ Weight of dry material and crucible at $105^{\circ} \mathrm{C}$ in the oven, $W_{4}=$ Weight of material and crucible after ignition at $55^{\circ} \mathrm{C}$.

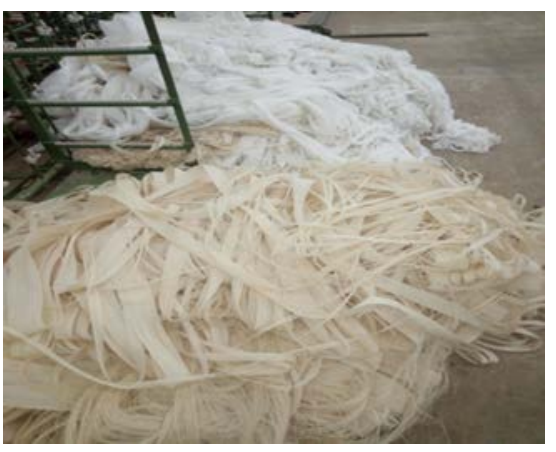

(a)

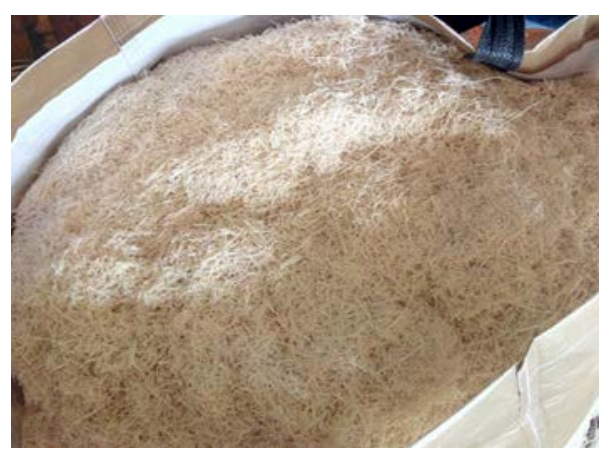

(b)

Figure 1. Cotton yarn wastes. (a) Bulk sample at Rivatex Eastern Africa Limited before collection; (b) after cutting into small pieces. 
A pen type $\mathrm{pH}$ meter (PH-009(I)A) was used for all $\mathrm{pH}$ measurements. Kheldahl method was used to determine the total nitrogen content which involved sample digestion followed by volumetric determination. Briefly, $1 \mathrm{~g}$ of the sample was weighed into a digestion flask together with a catalyst composed of $5 \mathrm{~g}$ of potassium sulphate and $0.5 \mathrm{~g}$ of copper (II) sulphate and $10 \mathrm{~mL}$ of concentrated (98\%) sulphuric acid $\left(\mathrm{H}_{2} \mathrm{SO}_{4}\right)$. The mixture was heated in a fume hood at $420^{\circ} \mathrm{C}$ till the digest color turned blue signifying the end of the digestion process. Then the digest was cooled at room temperature, transferred to a $100 \mathrm{~mL}$ volumetric flask and topped up to the mark with distilled water. An empty digestion tube (blank) with the catalysts and acid was also made. Measured $10 \mathrm{~mL}$ of the diluted digest was transferred into a distilling flask and washed with about $3 \mathrm{~mL}$ distilled water. An aliquot $(15 \mathrm{~mL})$ of $40 \%(\mathrm{w} / \mathrm{v}) \mathrm{NaOH}$ was added and this was also washed with about $3 \mathrm{~mL}$ distilled water. Distillation was done to a volume of about $60 \mathrm{~mL}$ distillate. The distillate was titrated using $0.02 \mathrm{~N} \mathrm{HCl}$ to the orange color of the mixed indicator (Methyl orange) which signified the end of the point.

Total carbon analysis was done using Walkey-Black potassium dichromate method as described by previous authors [28] [29]. Accurately weighed 1g of dry samples was put in $250 \mathrm{~mL}$ conical flasks and $10 \mathrm{~mL}$ of $1 \mathrm{~N}$ potassium dichromate solution $\left(\mathrm{K}_{2} \mathrm{Cr}_{2} \mathrm{O}_{7}\right)$ was added and swirled. Thereafter, $15 \mathrm{~mL}$ of $\mathrm{H}_{2} \mathrm{SO}_{4}$ was added in a fume hood swirled again three times. The flasks were allowed to stand for 30 minutes, and then $150 \mathrm{~mL}$ distilled water was added followed by $5 \mathrm{~mL}$ of ortho-phosphoric acid. The contents were titrated with $0.5 \mathrm{~N}$ ferrous ammonium sulphate solution till the color changed from blue to green.

\subsection{Experimental Conditions}

The experiments were conducted in duplicate using $2 \mathrm{~L}(8 \mathrm{~cm}$ diameter and 25 $\mathrm{cm}$ height) aspiration plastic bottles with working volumes of $1.5 \mathrm{~L}$ which were painted black to increase insulation [14]. The anaerobic digesters contained 150 $\mathrm{g}$ of inoculum and $338 \mathrm{~g}$ of prepared CYW and the remaining volume was topped up with water. Two batch fermenters were set at room temperature; two were buried in buckets filled with sawdust and two others were incubated in a water bath at $37^{\circ} \mathrm{C}$ (Figure $2 \&$ Figure 3 ). The batch experiments were performed under normal conditions for 30 days in the Chemical and Process Engineering Laboratory, Moi University, Kenya.

The substrate was prepared at the start of experiment and mixed before being added to the digester. The substrate was digested at $25 \%$ TS. The digesters were gently shaken once every week. During the experiment, biogas production was measured by water displacement method daily.The conical flask filled with water $(1 \mathrm{~L})$ and connected to a digester so that when gas was produced, water moved to a different conical flask $(500 \mathrm{~mL})$ then the displaced water was collected and measured using a measuring cylinder (Figure 3 ).

The biogas produced was standardized according to DIN 1343 (standard conditions; temperature $(\mathrm{T})={ }^{\circ} \mathrm{C}$ and pressure $(\mathrm{P})=1103$ bar) [30]. The biogas volume was normalized using Equation (4) [20] [30]. 


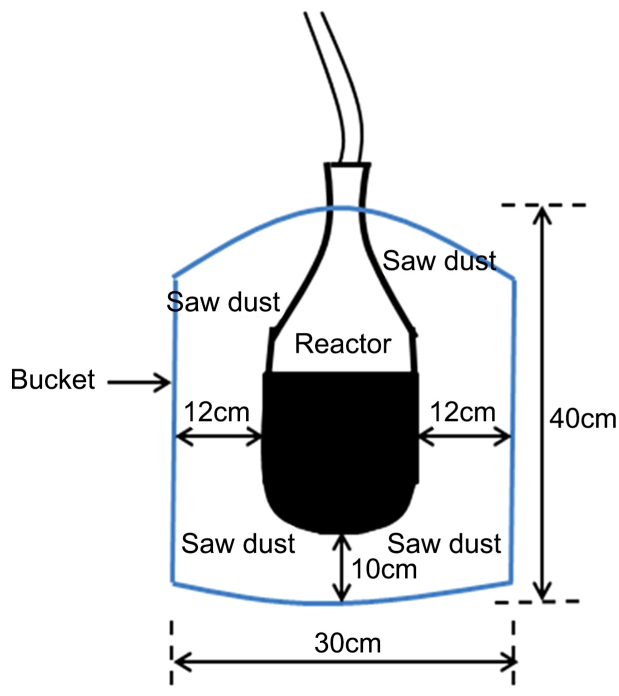

(a)

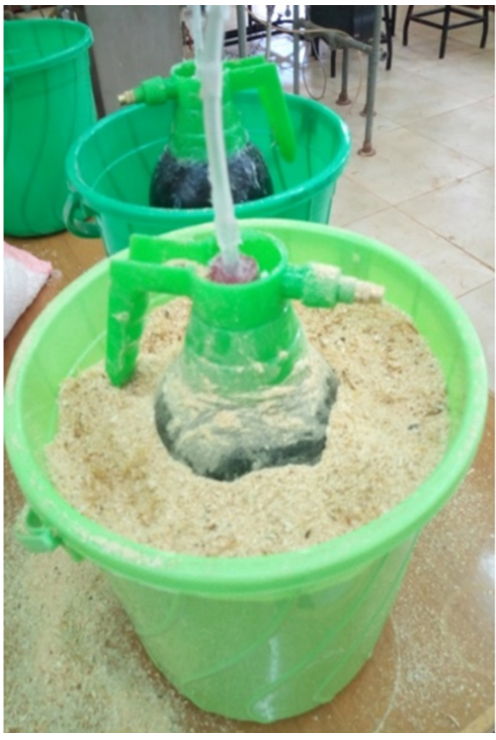

(b)

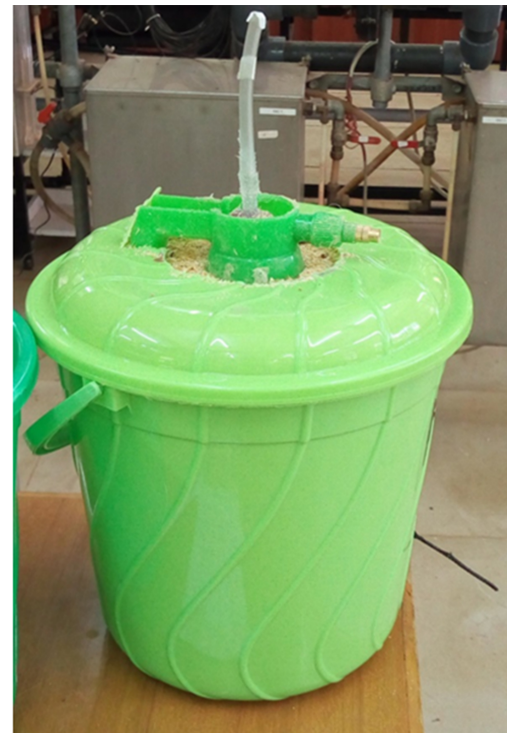

(c)

Figure 2. Overview of controlled digester with sawdust. (a) Schematic diagram; (b) and (c) experimental set ups.

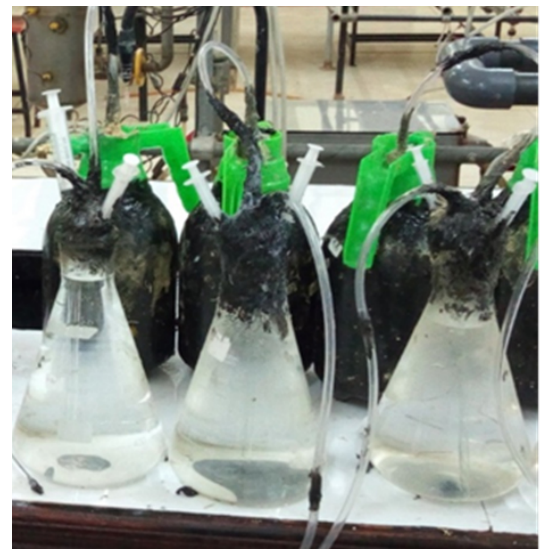

(a)

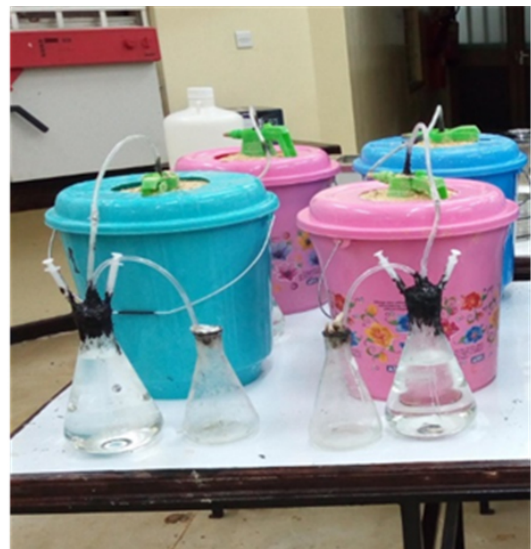

(b)

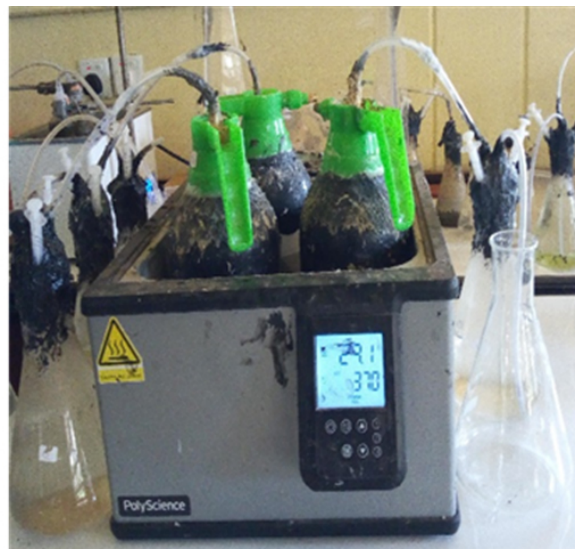

(c)

Figure 3. Full biogas setup. (a) Control digester (at room temperature); (b) digester in sawdust; (c) digester in water bath.

$$
V_{N}=\frac{V \times 273 \times\left(760-P_{W}\right)}{(273+T) \times 760}
$$

where $V_{N}=$ volume of dry biogas at standard conditions $(\mathrm{mL}), V=$ biogas volume recorded $(\mathrm{mL}), P_{W}=$ vapor pressure of water $(\mathrm{mmHg})$ and $T=$ room temperature $(\mathrm{K})$.

Normally, the digester gas is saturated with water vapor. Therefore, the water vapor pressure was calculated according to the modified Buck equation (Equation (5)) [30] [31].

$$
P_{W}=P(T)=4.5445 \times \exp ^{\left(18.678-\left(\frac{T}{234.5}\right)\left(\frac{T}{257.14+T}\right)\right)}
$$

From which $\mathrm{P}$ is the vapor pressure in $\mathrm{mmHg}$ and $\mathrm{T}$ is the temperature at the ambient space $\left({ }^{\circ} \mathrm{C}\right)$. The biogas yield $(Y)$ was calculated using Equation (6) [32]. 


$$
y=\frac{\text { Biogas production }(\mathrm{mL})}{V S_{\text {removed }}(g)}
$$

where

$$
V S_{\text {removed }}=V S_{\text {initial }}(g)-V S_{\text {final }}
$$

A multi-gas detector (SKY2000-M4-WH model) was used in the quantitative analysis of biogas produced.

\subsection{Statistical Analyses of Results}

All numerical results were subjected to preliminary statistical analysis where they were averaged, and the results presented as means \pm standard deviations of replicates. Past is free software for scientific data analysis, with functions for data manipulation, plotting, process statistical data, generate graphs and calculate various statistical indicators. Therefore, all statistical works were done in $\mathrm{Mi}$ crosoft Excel 2016 (Microsoft Corporation, USA) and Past statistical software (version 4.03).

\section{Results and Discussion}

\subsection{Temperature}

It is important to control the process temperature in biogas digesters to ensure good performance of microorganisms [33]. Throughout the experiment, the average ambient temperature measured was $20.63^{\circ} \mathrm{C} \pm 2.37^{\circ} \mathrm{C}$ while sawdust temperature was $22.16^{\circ} \mathrm{C} \pm 1.18^{\circ} \mathrm{C}$. Room temperature drifted from the design conditions of $15^{\circ} \mathrm{C}$ and $22^{\circ} \mathrm{C}$ throughout the course of the study (Figure 4). The average temperature (T4) of digester slurry (digester dipped in sawdust, D2), recorded from temperature loggers located inside sawdust and the digester settled at room temperature (D1) varied by as much as $2^{\circ} \mathrm{C}$ and $5^{\circ} \mathrm{C}$, respectively. The average temperature in each digester was $27.03^{\circ} \mathrm{C} \pm 0.18^{\circ} \mathrm{C}$ and $24.06^{\circ} \mathrm{C} \pm 0.18^{\circ} \mathrm{C}$, respectively. The average temperature measured in the digester dipped in sawdust was fairly constant and significantly higher (statistically different) than the control digester left at room temperature. Only slight changes on day 5, day 16 and day 25 were recorded for the digester in sawdust. The temperature of the digester slurry settled in the water bath (D3) was not measured. Apart from this, the plastic bottle digester showed some practical advantages due to adaptable conditions, keeping the warm as it was painted black.

\subsection{Physicochemical Characteristics of CYW and the Inoculum}

The characteristics of feedstock are important in designing and operating anaerobic digesters. The initial characteristics of feedstock strongly affect their biodegradability, quality and quantity of biogas produced as well as anaerobic stability [34] [35]. The physicochemical characteristics of CYW and inoculum are given in Table 1. 


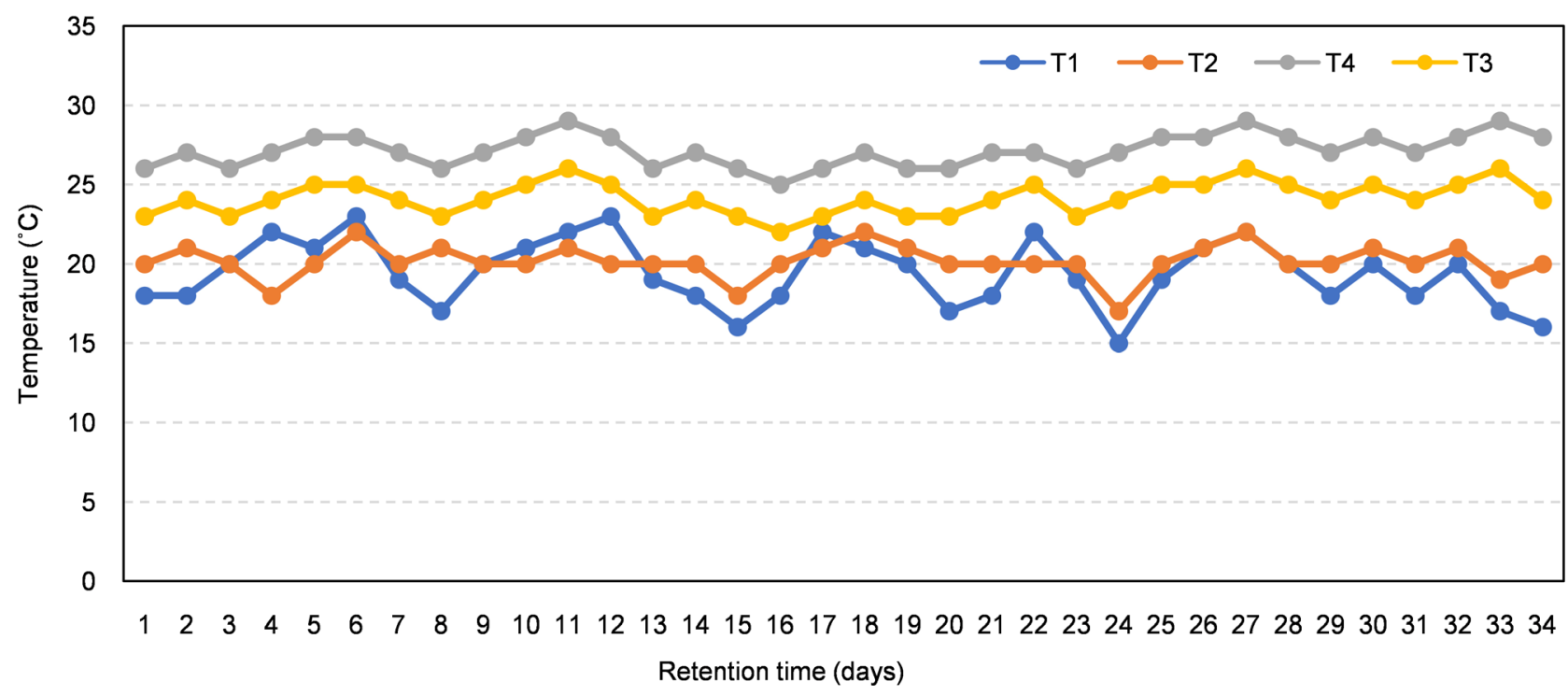

Figure 4. Comparison of room temperature (T1), sawdust temperature (T2) and temperature recorded in D1 slurry (T3) and temperature recorded in D2 slurry (T4).

Table 1. Physicochemical characteristics of the substrate and the inoculums.

\begin{tabular}{ccc}
\hline Parameter & Cotton yarn waste & Inoculum \\
\hline $\mathrm{pH}$ & $7.20 \pm 0.30$ & $6.50 \pm 0.20$ \\
Moisture content (\%) & $8.82 \pm 0.34$ & $91.67 \pm 0.65$ \\
Total solids (\%) & $91.18 \pm 0.58$ & $8.33 \pm 0.25$ \\
Volatile solids (\%TS) & $80.48 \pm 0.42$ & $87.64 \pm 0.45$ \\
Ash content (\%TS) & $19.52 \pm 0.35$ & $12.36 \pm 0.29$ \\
Carbon to nitrogen ratio & $41.31 \pm 0.34$ & $21.25 \pm 0.35$
\end{tabular}

Values are presented as means \pm standard deviations of triplicates.

The total solid content of the feedstock (CYW) was $91.18 \% \pm 0.58 \%$ and $8.33 \% \pm 0.25 \%$ for the inoculum. These are close to the TS contents of $90.46 \% \pm$ $0.20 \%$ and $9.36 \% \pm 0.20 \%$ for CYW previously reported in our laboratory [14]. Potential of gas production from the substrate depends on the VS loading of the reactor and the percentage of VS reduction through digestion [36]. Therefore, a substrate with high concentration of VS is the best for AD. In this study, the VS percentage of TS of CYW and inoculum were $80.48 \% \pm 0.42 \%$ and $87.64 \% \pm$ $0.45 \%$, respectively (Table 1 ). These are close to the VS contents of $77.12 \pm$ $0.20 \%$ and $85.64 \% \pm 0.10 \%$ for CYW previously reported by Twizerimana et al. [14]. Nevertheless, the values lie in the range of 70\% - 95\% necessary for efficient AD process [14] [37]. Further, the VS/TS ratio which expresses the degree of biodegradability of wastes was $85.25 \%$ for CYW which is indicative of its high biodegradability and suitability as a feedstock for biogas production [17] [38].

The $\mathrm{C} / \mathrm{N}$ ratio of the inoculum was 21.25:1 which is in a suitable range to keep 
the $\mathrm{AD}$ in a stable condition [39]. However, the CYW had high $\mathrm{C} / \mathrm{N}$ ratio of 41.31:1 and therefore not easily degraded. It was reiterated by previous authors that the optimum $\mathrm{C} / \mathrm{N}$ ratio of organic wastes harnessed for anaerobic biogas production should be 20 - 30:1 [40]. In practice, $\mathrm{C} / \mathrm{N}$ ratios of potential biogas feedstocks are frequently lower or higher than the suggested range [41]. Einarsson and Persson [42] therefore gave a different standpoint that both the $\mathrm{C} / \mathrm{N}$ ratio and TS content of organic wastes should be taken into consideration as they can both affect biogas production. The results of physiochemical properties of effluents from $\mathrm{AD}$ showed that there were decreases in the average TS and TVS. After digestion, the TS, TVS and MC were $21.61 \% \pm 0.13 \%, 23.61 \% \pm 0.23 \%$ and $78.38 \% \pm 0.56 \%$, respectively. The moisture content was high due to water addition before digestion and water that increased during hydrolysis process. Digester D2 showed a reduction in TS and VS of $37.00 \% \pm 0.22 \%$ and $40.00 \% \pm 0.34 \%$, respectively. Digester D3 represented the largest reduction among all digesters, $48 \%$ for TS and $61 \% \pm 0.18 \%$ for VS. Digester D1 showed the smallest reduction with TS of $25 \% \pm 0.31 \%$ and VS of $30 \% \pm 0.25 \%$. Possibly, the smallest reduction is due to the low availability of soluble organic matter for the activity of microorganisms [25] as it operated at the lowest temperature which ended up limiting biogas production and the reduction in the amount of VS. This suggests that low temperature is a disadvantage to both biological and physicochemical degradation of biogas substrates. Olanrewaju and Olubanjo [43] using poultry droppings, cow and swine dung reported that there was a reduction in the TS and VS as biogas yields increased. Reduction in TS and VS is an evidence of the efficiency of the $\mathrm{AD}$ process, associated with higher biogas production. In this study, substrates digested at $37^{\circ} \mathrm{C}$ exhibited relatively high biodegradation efficiency. Characterization of CYW showed that it had a relatively low moisture content, with high TS and VS content which showed that it is a potential feedstock for AD.

\subsection{Biogas Production}

Biogas production started soon after the start of the test, in variable but significant amounts. Daily rate of the biogas production was a little bit high for the first days and declined after 5 days and sharply started increasing, with the maximum daily rate of biogas production being achieved on days 11 and 12 for D2 and D3 with biogas yield of $136.17 \mathrm{~mL}$ per g-VS and $165.25 \mathrm{~mL}$ per g-VS, respectively. Only digester D1 showed its first biogas peaks at around 5 days (Figure 5), a fact that might be due to the lower temperature at which the digester was ran. Further, D1 had a high daily peak observed on day 13 with a biogas yield of 100.86 $\mathrm{mL}$ per $\mathrm{g}$-VS. It was also observed that the peaks of biogas showed similar behavior with increased production in the first days. The peaks of biogas production in the early days may be related to favorable temperatures and large quantities of easily biodegradable materials (carbohydrates, proteins and starch) which were present in CYW or may also be associated with the capacity for adaptation to the AD process by microorganisms in the substrate [14] [44] [45]. It was also ob- 
served that after the conversion of the easily biodegradable material fraction, the system needed to start the degradation of more complex compounds with a greater level of difficulty [46] [47]. Investigation of the effect of temperature on $\mathrm{AD}$ indicated that digester $\mathrm{D} 3$ operated at control temperature using water bath had higher biogas yield $(2481.23 \pm 5.50 \mathrm{~mL}$ per $\mathrm{g}$-VS $)$ as well as methane content $62.35 \%$ followed by digester (D2) in sawdust and then uncontrolled one (D1) with biogas yield of $1856.51 \pm 6.98 \mathrm{~mL}$ per g-VS, $52.45 \% \mathrm{CH}_{4}$ and $1084.29 \pm 5.71$ $\mathrm{mL}$ per g-VS, $45.28 \% \mathrm{CH}_{4}$ in retention time of 25 - 35 days respectively. The biogas compositions were analyze usinga multi-gas detector (SKY2000-M4-WH model, Gas type: $\mathrm{CO}_{2} / \mathrm{CH}_{4} / \mathrm{O}_{2} / \mathrm{H}_{2} \mathrm{~S}$ ) (Table 2). The results reaffirmed that temperature control has a significant effect on biogas production.

The results obtained for methane were within range of $40 \%-60 \%$ reported by preceding authors [48] [49] [50]. This suggests that microbial activity at room temperature was high and contributed to biogas production. The total average biogas

Table 2. Biogas composition from the different digesters.

\begin{tabular}{cccc}
\hline Component & $\begin{array}{c}\text { D1 (at room } \\
\text { temperature) }\end{array}$ & D2 (Sawdust) & D3 (in water bath) \\
\hline Methane & $45.58 \%$ & $52.85 \%$ & $62.75 \%$ \\
Carbon dioxide & $50.47 \%$ & $44.38 \%$ & $35.11 \%$ \\
Oxygen & $3.25 \%$ & $2.17 \%$ & $1.54 \%$ \\
Hydrogen sulfide & $254 \mathrm{ppm}$ & $215 \mathrm{ppm}$ & $200 \mathrm{ppm}$ \\
\hline
\end{tabular}

Values are averages of triplicate analyses.

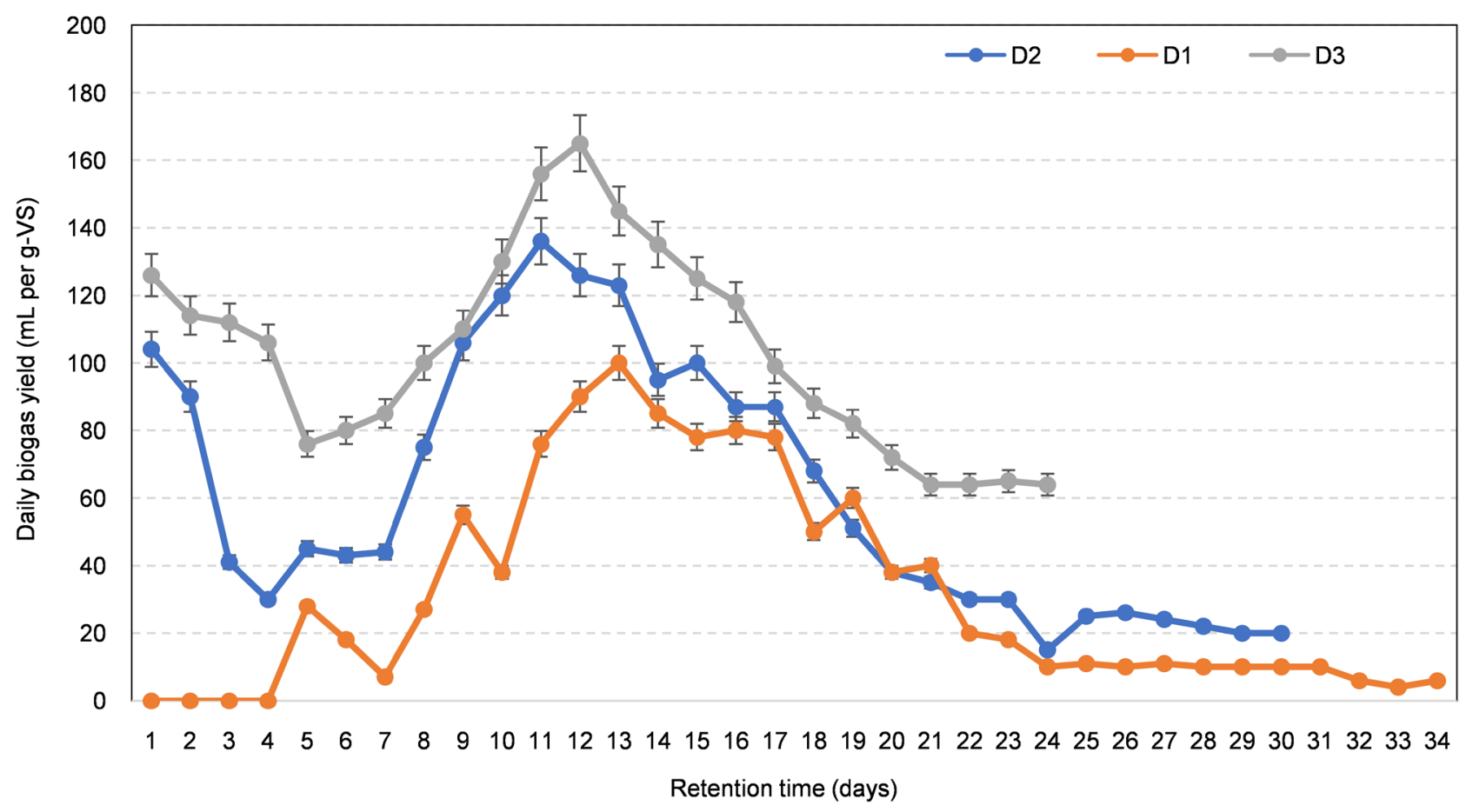

Figure 5. Daily cumulative biogas yield. 
yield reached was $2481.23 \pm 5.50 \mathrm{~mL}$ per g-VS. This showed efficiency of biogas production throughout the study. As temperature increases, biogasproduction rate is expected to increase until an optimum temperature is attained [22] [26]. Experimental results indicated that typical temperature control at higher temperatures cause decomposition to take place quickly (Figure 5). Figure 5 is often seen that biogas production was not ended at the same time. This is often predicted that the carbons contained by all of the digesters' constituents are not equally degraded or converted to biogas production.

Technically, only moderate and thermophilic temperatures are feasible and realistic, because $\mathrm{AD}$ is very slow at room temperature [51] [52]. However, the disadvantages of high-temperature $\mathrm{AD}$ are reduced process stability, reduced dehydration performance of fermented sludge, and a large amount of energy required for heating [52] [53]. This study has addressed such a challenge in a potential industrial biogas system by investigating the effect of sawdust on biogas production. The results indicated that sawdust has a potential of regulating the temperature in the required range for $\mathrm{AD}$ in biogas production.

\section{Conclusion}

The physicochemical characteristics of CYW showed that it is a suitable substrate for $\mathrm{AD}$ in biogas production. However, its $\mathrm{C} / \mathrm{N}$ ratio was high compared to the inoculum. The digester whose temperature was regulated using sawdust had biogas yields that were comparable to the one controlled using water bath $(1084.29 \pm 5.71 \mathrm{~mL}$ per g-VS and $2481.23 \pm 5.50 \mathrm{~mL}$ per g-VS, respectively in 25-35 days). Further studies should explore other locally available potential temperature regulators for potential replicability at room temperature.

\section{Acknowledgement}

The authors acknowledge the support from Africa Centre of Excellence II in Phytochemicals, Textiles and Renewable Energy (ACE II PTRE), Moi University which made this research a success.

\section{Funding}

This research was financially supported by the World Bank and the Inter-University Council of East Africa (IUCEA) through the Africa Centre of Excellence II in Phytochemicals, Textiles and Renewable Energy (ACE II PTRE) hosted at Moi University, Kenya (Credit No. 5798-KE). The support was awarded to Maurice Twizerimana. The funders however, had no role in study design, data collection and analysis, preparation of the manuscript and/or the decision to publish.

\section{Conflicts of Interest}

The authors declare no conflicts of interest.

\section{References}

[1] Winquist, E., Galen, M. V., Zielonka, S., Rikkonen, P., Oudendag, D., Zhou, L. and 
Greijdanus, A. (2021) Expert Views on the Future Development of Biogas Business Branch in Germany, the Netherlands, and Finland until 2030, Sustainability, 13, Article No. 1148. https://doi.org/10.3390/su13031148

[2] Mulu, E., M’Arimi, M.M. and Ramkat, R. C. (2021) A Review of Recent Developments in Application of Low-Cost Natural Materials in Purification and Upgrade of Biogas. Renewable and Sustainable Energy Reviews, 145, Article No. 111081. https://doi.org/10.1016/j.rser.2021.111081

[3] Rabii, A., Aldin, S., Dahman, Y. and Elbeshbishy, E. (2019) A Review on Anaerobic Co-Digestion with a Focus on the Microbial Populations and the Effect of MultiStage Digester Configuration. Energies, 12, Article No. 1106. https://doi.org/10.3390/en12061106

[4] Muhayodin, F., Fritze, A. and Rotter, V.S. (2020) A Review on the Fate of Nutrients and Enhancement of Energy Recovery from Rice Straw through Anaerobic Digestion. Applied Sciences, 2020, Article No. 2047. https://doi.org/10.3390/app10062047

[5] Wang, K., Yin, J., Shen, D. and Li, N. (2014) Anaerobic Digestion of Food Waste for Volatile Fatty Acids (VFAs) Production with Different Types of Inoculum: Effect of pH. Bioresource Technology, 163, 395-401. https://doi.org/10.1016/j.biortech.2014.03.088

[6] Alfarjani, F.A. (2012) Design and Optimization of Process Parameters in Bio-Gas Production Systems. Master Thesis, Dublin City University, Dublin.

[7] Zeb, B.S., Mahmood, Q. and Pervez, A. (2014) Anaerobic Wastewater Treatment, Process Performance and Optimization. Journal of Chemical Society of Pakistan, 35, $1-17$.

[8] Horváth, I.S., Tabatabaei, M., Karimi, K. and Kumar, R. (2016) Recent Updates on Biogas Production-A Review. Biofuel Research Journal, 3, 394-402.

https://doi.org/10.18331/BRJ2016.3.2.4

[9] Mcvoitte, W.P.A. and Clark, O.G. (2019) The Effects of Temperature and Duration of Thermal Pretreatment on the Solid-State Anaerobic Digestion of Dairy Cow Manure. Heliyon, 5, Article No. E02140. https://doi.org/10.1016/j.heliyon.2019.e02140

[10] Liua, C., Wachemoa, A.C., Tonga, H., Shia, S., Zhanga, L., Yuana, H. and Li, X. (2017) Biogas Production and Microbial Community Properties during Anaerobic Digestion of Corn Stover at Different Temperatures. Bioresource Technology, 261, 93-103. https://doi.org/10.1016/j.biortech.2017.12.076

[11] Balasubramaniyam, U., Zisengwe, L.S., Meriggi, N. and Buysman, E. (2008) Biogas Production in Climates with Long Cold Winters. Wageningen University, Netherlands.

[12] Isci, A. and Demirer, G.N. (2007) Biogas Production Potential from Cotton Wastes. Renewable Energy, 32, 750-757. https://doi.org/10.1016/j.renene.2006.03.018

[13] Rasel, M., Zerin, I., Bhuiyan, S.H., Hoque, K.M.H., Hasan, M. and Alam, M.M. (2019) Industrial Waste Management by Sustainable Way. European Journal of Engineering Research and Science, 4, 111-114. https://doi.org/10.24018/ejers.2019.4.4.1225

[14] Twizerimana, M., Marimi, M., Bura, X. and Nganyi, E.O. (2020) Biogas Production from Co-Digestion of Cotton Yarn Waste and Human Urine. Journal of Energy Research and Reviews, 6, 20-29. https://doi.org/10.9734/jenrr/2020/v6i130158

[15] Dennis, O.E. (2015) Effect of Inoculums on Biogas Yield. IOSR Journal of Applied Chemistry, 8, 5-8.

[16] Vögeli, Y., Lohri, C.R., Gallardo, A., Diener, S. and Zurbrügg, C. (2014) Anaerobic 
Digestion of Biowaste in Developing Countries. Eawag-Swiss Federal Institute of Aquatic Science and Technology, Dübendorf.

[17] Walter, K. and Culhane, T. (2009) Improving Cold Season Biogas Digester Efficiency for Global Energy Solutions. Institute Northern Engineering, University of Alaska Fairbanks, College.

[18] Ghatak, M.D. and Mahanata, P. (2018) Effect of Temperature on Biogas Production from Rice Straw and Rice Husk. IOP Conference Series. Materials Science and Engineering, 377, Article No. 012146. https://doi.org/10.1088/1757-899X/377/1/012146

[19] Wang, S., Ma, F., Ma, W., Wang, P., Zhao, G. and Lu, X. (2019) Influence of Temperature on Biogas Production Efficiency and Microbial Community in a Two-Phase Anaerobic Digestion System. Water, 11, Article No. 133.

https://doi.org/10.3390/w11010133

[20] Pham, C.H., Vu, C.C., Sommer, S.G. and Bruun, S. (2014) Factors Affecting Process Temperature and Biogas Production in Small-Scale Rural Biogas Digesters in Winter in Northern Vietnam. Asian-Australasian Journal of Animal Science, 27, 1050-1056. https://doi.org/10.5713/ajas.2013.13534

[21] Christy, P.M., Gopinath, L.R. and Divya, D. (2014) A Review on Anaerobic Decomposition and Enhancement of Biogas Production through Enzymes and Microorganisms. Renewable and Sustainable Energy Reviews, 34, 167-173.

https://doi.org/10.1016/j.rser.2014.03.010

[22] Park, Y.J., Tsuno, H., Hidaka, T. and Cheon, J.H. (2008) Evaluation of Operational Parameters in Thermophilic acid Fermentation of Kitchen Waste. Journal of Materials and Cycles Waste Management, 10, 46-52. https://doi.org/10.1007/s10163-007-0184-y

[23] Prasad, R.D. (2012) Empirical Study on Factors Affecting Biogas Production. International Scholarly Research Network, 2012, Article ID: 136959. https://doi.org/10.5402/2012/136959

[24] Nekhubvi, V. and Tinarwo, D. (2017) Long-Term Temperature Measurement: Biogas Digesters Fermenting Slurry. Journal of Energy South Africa, 28, 99-106. https://doi.org/10.17159/2413-3051/2017/v28i3a1437

[25] Teleszewski, T.J. and Żukowski, M. (2018) Analysis of Heat Loss of a Biogas Anaerobic Digester in Weather Conditions in Poland. Journal of Ecological Engineering, 19, 242-250. https://doi.org/10.12911/22998993/89660

[26] Water Environmental Federation (1999) Standard Methods for the Examination of Water and Wastewater, Part 1000. Water Environmental Federation, Alexandria.

[27] Hasanzadeh, E., Mirmohamadsadeghi, S. and Karimi, K. (2017) Enhancing Energy Production from Waste Textile by Hydrolysis of Synthetic Parts. Fuel, 218, 41-48. https://doi.org/10.1016/j.fuel.2018.01.035

[28] Myovela, H. (2018) Anaerobic Digestion of Spineless Cacti (Opuntia Ficus-Indica (L.) Mill) Biomass in Tanzania: The Effects of Aerobic Pre-Treatment. Master Thesis, Pan African University Institute of Science, Technology and Innovation, Nairobi.

[29] Bakr, N. and El-ashry, S.M. (2018) Organic Matter Determination in Arid Region Soils: Loss-on-Ignition versus Wet Oxidation. Communications in Soil Science and Plant Analysis, 49, 2587-2601. https://doi.org/10.1080/00103624.2018.1526947

[30] Jan, G. and Euverink, W. (2019) Elevated Biogas Production from the Anaerobic Co-Digestion of Farmhouse Waste: Insight into the Process Performance and Kinetics. Waste Management \& Resources, 37, 1240-1249. 
https://doi.org/10.1177\%2F0734242X19873383

[31] Fleck, L., Tavares, M.H.F., Eyng, E., De Andrade, M.A. and Frare, M.L. (2017) Optimization of Anaerobic Treatment of Cassava Processing Wastewater. Engenharia Agrícola, 37, 574-590. https://doi.org/10.1590/1809-4430-Eng.Agric.v37n3p574-590/2017

[32] Jaroenpoj, S. (2015) Biogas Production from Co-Digestion of Landfill Leachate and Pineapple Peel. Ph.D. Thesis, Griffith University, Queensland.

[33] Drosg, B. (2013) Process Monitoring in Biogas Plants. IEA (International Energy Agency) Bioenergy, Paris.

[34] Bong, C.P.C., Lim, L.Y., Lee, C.T., Klemeš, J.J., Ho, C.S. and Ho, W.S. (2017) The Characterization and Treatment of Food Waste for Improvement of Biogas Production during Anaerobic Digestion-A Review. Journal of Cleaner Production, 172, 1545-1588.

[35] Aslanzadeh, S. (2014) Pretreatment of Cellulosic Waste and High-Rate Biogas Production. Master Thesis, University of Borås, Borås.

[36] Adebayo, G.B. and Odedele, O.S. (2020) Production and Characterization of Biogas from Domestic Waste by Anaerobic Digestion. International Journal of Environmental and Bioenergy, 15, 1-9.

[37] Getahun, T., Gebrehiwot, M., Ambelu, A., Van Gerven, T. and Van der Bruggen, B. (2014) The Potential of Biogas Production from Municipal Solid Waste in a Tropical Climate. Environmental and Monitoring Assessment, 186, 4637-4646. https://doi.org/10.1007/s10661-014-3727-4

[38] Gaur, R.Z. and Suthar, S. (2017) Anaerobic Digestion of Activated Sludge, Anaerobic Granular Sludge and Cow Dung with Food Waste for Enhanced Methane Production. Journal of Cleaner Production, 164, 557-566. https://doi.org/10.1016/j.jclepro.2017.06.201

[39] Bambokela, E.J., Matheri, A.N., Belaid, M., Agbenyeku, E.E. and Muzenda, E. (2016) Impact of Substrate Composition in Biomethane Production under Thermophilic Conditions. International Conference on Advances in Science, Engineering, Technology and Natural Resources (ICASETNR-16), Parys, 24-25 November 2016, 44-48.

[40] Habiba, L., Hassib, B. and Moktar, H. (2009) Bioresource Technology Improvement of Activated Sludge Stabilization and Filterability during Anaerobic Digestion by Fruit and Vegetable Waste Addition. Bioresource Technology, 100, 1555-1560. https://doi.org/10.1016/j.biortech.2008.09.019

[41] Patinvoh, R.J., Osadolor, O.A., Chandolias, K., Sárvári Horváth, I. and Taherzadeh, M.J. (2017) Innovative Pretreatment Strategies for Biogas Production. Bioresource Technology, 224, 13-24. https://doi.org/10.1016/j.biortech.2016.11.083

[42] Einarsson, R. and Persson, U.M. (2017) Analyzing Key Constraints to Biogas Production from Crop Residues and Manure in the EU-A Spatially Explicit Model. PLOS ONE, 12, e0171001. https://doi.org/10.1371/journal.pone.0171001

[43] Olanrewaju, O.O. and Olubanjo, O.O. (2019) Development of a Batch-Type Biogas Digester Using a Combination of Cow Dung, Swine Dung and Poultry Dropping. International Journal of Clean Coal Energy, 8, 15-31. https://doi.org/10.4236/ijcce.2019.82002

[44] Gu, Y., Chen, X., Liu, Z., Zhou, X. and Zhang, Y. (2014) Effect of Inoculum Sources on the Anaerobic Digestion of Rice Straw. Bioresource Technology, 158, 149-155. https://doi.org/10.1016/j.biortech.2014.02.011

[45] Nayono, S.E. (2009) Anaerobic Digestion of Organic Solid Waste for Energy Pro- 
duction. PhD. Thesis, Universität Karlsruhe, Karlsruhe.

[46] Parawira, W., Murto, M., Zvauya, R. and Mattiasson, B. (2004) Anaerobic Batch Digestion of Solid Potato Waste alone and in Combination with Sugar beet Leaves. Renewable Energy, 29, 1811-1823. https://doi.org/10.1016/j.renene.2004.02.005

[47] Xia, T., Huang, H., Wu, G., Sun, E., Jin, X. and Tang, W. (2018) The Characteristic Changes of Rice Straw Fibers in Anaerobic Digestion and Its Effect on Rice StrawReinforced Composites. Industrial Crop and Products, 121, 73-79. https://doi.org/10.1016/j.indcrop.2018.04.004

[48] Monnet, F. (2003) An Introduction to Anaerobic Digestion of Organic Wastes. Final Report. Remade Scotland.

[49] Mir, M.A., Hussain, A. and Verma, C. (2016) Design Considerations and oPerational Performance of Anaerobic Digester: A Review. Cogent Engineering, 3, Article ID: 1181696. https://doi.org/10.1080/23311916.2016.1181696

[50] Wei, J. and Wang, J. (2013) Enhanced Hydrolysis and Methane Yield by Applying Microaeration Pretreatment to the Anaerobic Co-Digestion of Brown Water and Food Waste. Waste Management, 33, 813-819. https://doi.org/10.1016/j.wasman.2012.11.013

[51] Labatut, R.A., Angenent, L.T. and Scott, N.R. (2014) Conventional Mesophilic vs. Thermophilic Anaerobic Digestion: A Trade-Off between Performance and Stability? Water Resources, 53, 249-258. https://doi.org/10.1016/j.watres.2014.01.035

[52] Ziganshin, A.M., Liebetrau, J., Pröter, J. and Kleinsteuber, S. (2013) Microbial Community Structure and Dynamics during Anaerobic Digestion of Various Agricultural Waste Materials. Applied Microbiology and Biotechnology, 97, 5161-5174. https://doi.org/10.1007/s00253-013-4867-0

[53] Treichel,d H. and Fongaro, G. (2019) Improving Biogas Production-Technological Challenges, Alternative Sources, and Future Developments. Springer, Cham. https://doi.org/10.1007/978-3-030-10516-7 